\title{
Free secretory component and lactoferrin of human milk inhibit the adhesion of enterotoxigenic Escherichia coli
}

\author{
L. G. GIUGliANO, S. T. G. RIBEIRO, M. H. VAINSTEIN and C. J. ULHOA* \\ Laboratórios de Microbiologia e * Enzimologia, Departamento de Biologia Celular, Instituto de Biologia, \\ Universidade de Brasilia, 70910-900 Brasilia DF, Brazil
}

\begin{abstract}
Summary. The non-immunoglobulin component of human milk responsible for the inhibition of Escherichia coli cell adhesion (haemagglutination) mediated by colonisation factor antigen 1 (CFA1) was determined by chromatographic fractionation of human whey proteins with Sephadex G-200, DEAE cellulose and heparin-sepharose. Pure free secretory component (fSC) and pure lactoferrin (Lf) were isolated and both compounds inhibited the haemagglutination induced by $E$. coli $\mathrm{CFAl}^{+}$. The lowest concentrations of purified $\mathrm{fSC}$ and $\mathrm{Lf}$ able to inhibit the haemagglutination induced by $E$. coli strain TR50/3 CFA1 ${ }^{+}$were $0.06 \mathrm{mg} / \mathrm{ml}$ and $0.1 \mathrm{mg} / \mathrm{ml}$ respectively. Commercially available lactoferrin from human milk and transferrin from human serum, which has a great structural analogy to lactoferrin, also inhibited the haemagglutination. The lowest concentrations of the commercial lactoferrin and transferrin able to inhibit the haemagglutination induced by $E$. coli TR50/3 CFA1 ${ }^{+}$were $0.03 \mathrm{mg} / \mathrm{ml}$ and $0.4 \mathrm{mg} / \mathrm{ml}$, respectively. These results indicate that $\mathrm{fSC}$ and Lf may be important non-specific defence factors against enterotoxigenic $E$. coli infections.
\end{abstract}

\section{Introduction}

Enterotoxigenic Escherichia coli (ETEC) is one of the pathogens isolated most frequently from children with diarrhoea in developing countries. ${ }^{1-3}$ The ability of human ETEC strains to adhere to and colonise the intestinal epithelium is associated with the presence of colonisation factor antigens (CFA) in the bacterial surface. ${ }^{4}$ Several CFAs have been characterised but CFAl is the one found most frequently in ETEC strains. ${ }^{5,6}$

Many epidemiological studies of diarrhoea have shown that breast feeding protects infants from intestinal infections. ${ }^{7,8}$ The protective effect of human milk has been attributed to its immunoglobulin content, mainly to secretory immunoglobulin A (sIgA), ${ }^{9-11}$ and to non-specific defence factors such as lactoferrin (Lf), lysozyme, bifidus factor and oligosaccharides. ${ }^{9,12-15}$

Lf is an $80-\mathrm{kDa}$ glycoprotein, found in high concentrations in human milk, ${ }^{12,16}$ which has been shown to inhibit bacterial growth in vitro. This property is ascribed to its iron binding capacity that leads to iron deprivation for the micro-organism. ${ }^{12,17,18}$ It is also known that $\mathrm{Lf}$ binds to various microbial pathogens ${ }^{19-22}$ and this binding seems to enhance its antimicrobial capacity. ${ }^{23}$ Moreover, study of the specific binding of $\mathrm{Lf}$ to enteropathogenic (EPEC), enterotoxigenic (ETEC), enteroinvasive (EIEC) and enterohaemorrhagic (EHEC) strains of $E$. coli showed that ETEC strains bound more $\mathrm{Lf}$ than the other groups of enteropathogens. ${ }^{24}$

The protective effect of human milk has also been thought to be due to milk components that could act as cell receptor analogues for bacterial adhesins and enterotoxins. As the cell receptors are probably glycoconjugates containing a receptor-specific oligosaccharide moiety, ${ }^{25-27}$ the receptor analogues should be glycocompounds. Indeed, it has been shown that fucosylated oligosaccharides are associated with the inhibition of CFA1- and CFA2-mediated adhesion of ETEC strains ${ }^{26}$ and inhibit localised adhesion of EPEC strains. ${ }^{9}$

Human milk contains many glycocompounds, some of which are rich in fucosylated oligosaccharides, such as Lf and free secretory component (fSC), which are found in abundance. ${ }^{12,16,28-30}$ The secretory component (SC) mediates the transport of SIgA into external fluids on mucosal epithelial cells, and can be found in secretions both complexed with sIgA (bound $\mathrm{SC}$ ) or as an uncomplexed $80-\mathrm{kDa}$ glycoprotein called free SC. ${ }^{31-33}$

This study investigated a possible role for glycoproteins from human milk in the inhibition of the 
adhesion (haemagglutination) induced by ETEC $\mathrm{CFA} 1^{+}$strains, assaying, step by step, every fraction obtained in the chromatographic fractionation of the milk.

\section{Materials and methods}

\section{Breast milk samples}

Human milk samples were obtained from the Human Milk Bank of the Hospital Regional da Asa Sul (Brasilia DF). Aliquots of individual frozen samples were taken from at least 10 lactating mothers up to 1 month after delivery and pooled.

\section{Fractionation of human milk}

The pooled human milk was diluted with an equal volume of buffer $(0.1 \mathrm{M}$ Tris- $\mathrm{HCl}, \mathrm{pH} 7 \cdot 6$, supplemented with $0.5 \mathrm{M} \mathrm{NaCl}, 1 \mathrm{~mm}$ phenylmethanesulphonyl fluoride, $\mathrm{NaN}_{3} 0.1 \%$ and $50 \mathrm{mM} \varepsilon$-amino $n$-caproic acid). The mixture was centrifuged at $15000 \mathrm{~g}$ at $4^{\circ} \mathrm{C}$ for $1 \mathrm{~h}$ to remove lipids and cells. The middle layer was collected, acidified to $\mathrm{pH} 4.2$ with acetic acid $2 \%$ and centrifuged at $15000 \mathrm{~g}$ for $40 \mathrm{~min}$ to remove casein. The clear supernatant fluid was removed and its $\mathrm{pH}$ was adjusted to neutrality with $0.1 \mathrm{M} \mathrm{NaOH}$. Ammonium sulphate was added to $70 \%$ final saturation and the mixture was kept overnight at $4^{\circ} \mathrm{C}$. The precipitate which formed was collected by centrifugation, dissolved in the buffer and dialysed overnight at $4^{\circ} \mathrm{C}$ against the buffer. The sample was then applied to a Sephadex G-200 column equilibrated with the buffer.

\section{Purification of human milk fSC}

Purification of fSC from the fractions eluted in the second peak after Sephadex G-200 chromatography was performed as described previously. ${ }^{34}$ Briefly, the fractions were pooled and dialysed against $0.01 \mathrm{M}$ Tris$\mathrm{HCl}, \mathrm{pH} 7 \cdot 6$, containing $0.05 \mathrm{M} \mathrm{NaCl}$, and applied to a DEAE cellulose column equilibrated with the same buffer. Free SC is not retained and was eluted by washing the column with the buffer. For further purification, the eluted material was concentrated by adding $\left(\mathrm{NH}_{4}\right)_{2} \mathrm{SO}_{4}$ to $70 \%$ final saturation. The precipitate which formed was collected by centrifugation and subsequently dissolved in and dialysed overnight at $4^{\circ} \mathrm{C}$ against $0.05 \mathrm{M}$ Tris- $\mathrm{HCl}, \mathrm{pH} 8.0$, containing $0.2 \mathrm{M} \mathrm{NaCl}$. This material was then applied to a heparin-sepharose affinity column equilibrated with the same buffer.

\section{Electrophoretic procedures}

The protein content of the fractions was measured by the method of Bradford. ${ }^{35}$

All fractions from the chromatographic procedures were monitored before pooling by SDS-PAGE on acrylamide $10 \%$ gels by the method of Laemmli. ${ }^{36}$ Fractions from the heparin-sepharose chromatography were concentrated by precipitation with trichloro-acetic acid $10 \%$ before electrophoresis. Gels were stained with Coomassie Brilliant Blue $\mathrm{G}$ and also with silver. ${ }^{37}$

Two-dimensional electrophoresis was performed ${ }^{38}$ and the gels were stained with silver.

\section{Purification of lactoferrin}

Purified Lf was obtained either as a co-purification product of the procedure used to obtain fSC, or by a single chromatographic step on a heparin-sepharose column equilibrated with $5 \mathrm{~mm}$ Veronal- $\mathrm{HCl}$ buffer, $\mathrm{pH} 7.4$, containing $0.05 \mathrm{M} \mathrm{NaCl}^{39}$ Lf binds more strongly to heparin-sepharose than do the other whey proteins, and it can be eluted from the resin in a pure form with c. $0.6 \mathrm{M} \mathrm{NaCl}$.

\section{Inhibition assay}

The test system used was agglutination of human group A erythrocytes by ETEC $\mathrm{CFA} 1^{+}$-mediated adhesion. ${ }^{40,41}$ The ETEC CFA $1^{+}$strains used were TR 50/3, kindly provided by Dr B. C. Guth, Escola Paulista de Medicina, São Paulo, Brazil and m452-C1 and CD79a provided by Dr J. Blanco, Universidade de Santiago de Compostela, Lugo, Spain. The erythrocytes were collected in sodium citrate and washed three times in saline. The bacterial strains were grown overnight in CFA medium, ${ }^{42}$ harvested, washed two or three times in saline and resuspended in saline to a concentration of 300 Klett units (measured in a Klett-Summerson photo-electric colorimeter fitted with a green filter), equivalent to $1.5 \times 10^{9} \mathrm{cfu} / \mathrm{ml}$.

The milk samples or fractions to be analysed were serially diluted in $25 \mu \mathrm{l}$ of saline in plastic microtitration trays (Linbro Chemical Co., Inc., New Haven, CT, USA). To each well, $25 \mu 1$ of the bacterial suspension was added and the trays were first incubated for $15 \mathrm{~min}$ at room temperature and then kept for $2 \mathrm{~h}$ at $4^{\circ} \mathrm{C}$. Subsequently, $25 \mu \mathrm{l}$ of the washed erythrocytes $3 \%$ in saline containing D-mannose $4 \%$ were added and the trays were kept for $2 \mathrm{~h}$ at $4^{\circ} \mathrm{C}$. The haemagglutination pattern observed was graded from - (no agglutination) to ++++ (complete agglutination) and the $50 \%$ agglutination reaction was determined by interpolation when needed.

The highest dilution that inhibited $50 \%$ of the haemagglutination reaction was considered to be the inhibition titre of the fraction tested.

\section{Reagents}

The reagents were from Sigma and the resins from Pharmacia, Uppsala.

\section{Results}

Our preliminary studies on adhesion inhibition induced by human milk verified that both the dialysed 
precipitate from human whey obtained with ammonium sulphate at $50 \%$ saturation, which contains most of the immunoglobulins of the milk, ${ }^{34}$ and also the supernate, were capable of inhibiting haemagglutination by the ETEC CFA1 ${ }^{+}$strains. By increasing the ammonium sulphate to $70 \%$ saturation, the inhibition capacity was detected only in the precipitate. Furthermore, treatment of the precipitate obtained at $50 \%$ ammonium sulphate saturation and its supernate with trypsin increased the inhibition titre of both, whereas treatment with sodium metaperiodate decreased or abolished their inhibitory activity (results not shown). These preliminary results led us to the hypothesis that the human milk non-immunoglobulin component responsible for the inhibition was a complexed glycoprotein, because it was precipitated with ammonium sulphate, further activated by trypsin and inactivated by sodium metaperiodate.

The inhibition titre of the whey proteins obtained by precipitation at $70 \%$ ammonium sulphate was always $>256$ for all the ETEC CFA1 ${ }^{+}$strains tested, whereas the supernate did not inhibit the reaction.

Every fraction obtained from the fractionation of the human milk was tested for its capacity to inhibit haemagglutination induced by $E$. coli $\mathrm{CFA1}^{+} \mathrm{TR}^{+} 50 / 3$ and was also analysed by SDS-PAGE.

\section{Chromatographic fractionation}

A typical profile of human whey proteins eluted from the Sephadex G-200 column is shown in fig. 1. The fractions from the first peak (P1-S), containing mainly $\operatorname{sIgA},{ }^{34}$ inhibited the haemagglutination induced by the ETEC CFA1 ${ }^{+}$, as did the second peak (P2-S), that contained the free secretory component. This chromatographic step was repeated several times and the highest inhibition titres induced by P1-S and P2-S were always similar, varying between 64 and 128 . Fractions from P1-S analysed by SDS-PAGE presented a typical profile of $\operatorname{sIgA}$, showing three protein bands corresponding to the $\mathrm{SC}$, heavy chain and light chain, with estimated mol. wts of 79, 57 and $21 \mathrm{kDa}$ respectively (fig. 2, lane 2 ). The most inhibitory fractions from P2-S showed two main proteins of $79 \mathrm{kDa}$ (corresponding to fSC) and $60 \mathrm{kDa}$ (fig. 2, lane 3). All active fractions with the same electrophoretic pattern were pooled and applied to a DEAE cellulose column. With this procedure, $\mathrm{fSC}$ is not retained by the resin and is eluted by washing the column with the starting buffer ${ }^{34}$ The proteins bound to the DEAE were eluted by washing the column with the same buffer supplemented with $1 \mathrm{M} \mathrm{NaCl}$. Fig. 3 shows the elution pattern of the pooled fractions from P2-2 in ion exchange chromatography, and the titre of inhibition of some representative fractions. Most of the activity was found in the fractions containing the proteins not retained by the column (P1-D), but a six-fold lower activity was also detected in the fractions containing the proteins that were bound to the DEAE (P2-D). Electrophoretic analyses of the active fractions of
P1-D showed one main protein of $c .79 \mathrm{kDa}$ (fig. 2, lane 4). However, when the active fractions were pooled and concentrated with ammonium sulphate at $70 \%$ saturation, small amounts of two more proteins of lower mol. wt were also found. This result indicated, as expected, that the main compound of P1-D was a 79-kDa protein which corresponds to $\mathrm{fSC}$.

Because the most prevalent contaminant in the purification of fSC is lactoferrin, ${ }^{34}$ which has a mol. wt of $c .80 \mathrm{kDa}$, and two-dimensional electrophoresis of the concentrated P1-D fractions showed two proteins of approximately the same mol.wt but with very distinct iso-electric points to be present (fig. 5A), it was thought that Lf was also present with fSC in P1-D. Therefore, the pooled and concentrated fractions of P1-D were applied to a heparin-sepharose column to remove lactoferrin and any other whey proteins basic enough to have affinity to the strongly negatively charged resin. With the procedure used, fSC was not adsorbed by the column and was eluted by washing the

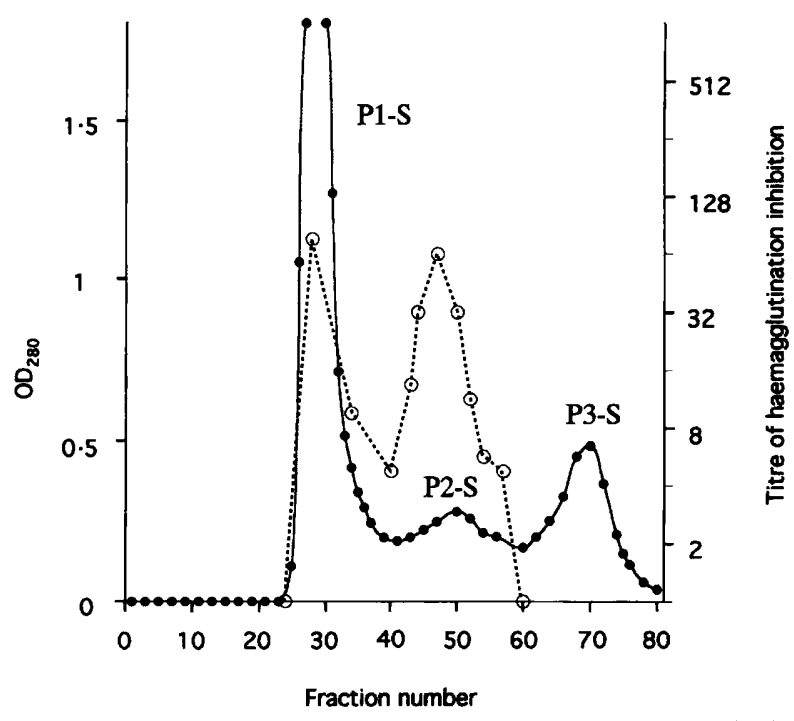

Fig. 1. Chromatography of the human milk proteins on Sephadex G- 200 column $(2 \cdot 1 \mathrm{~cm} \times 92 \mathrm{~cm})$. The peaks were monitored at $280 \mathrm{~nm}(--)$ and eluted with $0.1 \mathrm{M}$ Tris- $\mathrm{HCl}, \mathrm{pH} 7 \cdot 6$; the flow rate was $20 \mathrm{ml} / \mathrm{h}$. Fractions of $5 \mathrm{ml}$ were collected and assayed for inhibition of the haemagglutination (---O--) induced by $E$. coli $\mathrm{CFA1}^{+}$TR $50 / 3$.

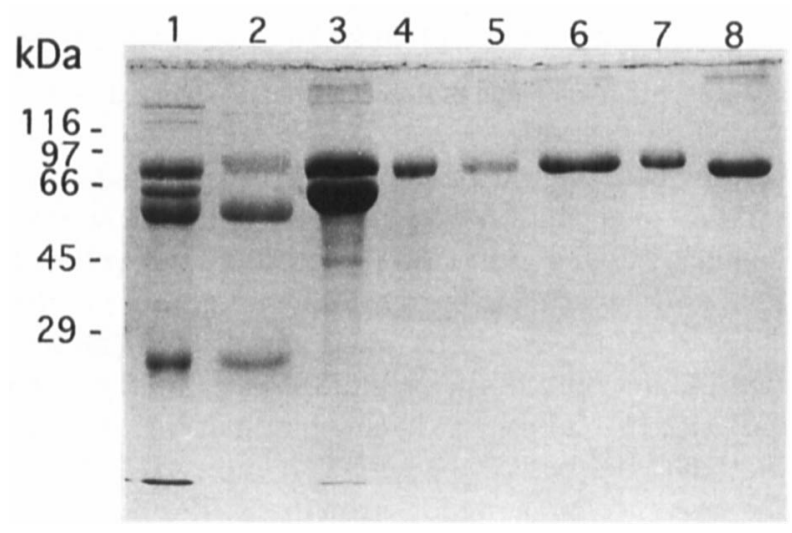

Fig. 2. SDS-PAGE of human milk fractions stained with Coomassie Blue. Lane 1, whey proteins precipitated with ammonium sulphate at $70 \%$ saturation; $2, \mathrm{P} 1-\mathrm{S} ; 3$, P2-S ; 4, P1-D ; 5, fraction 7 from P1$\mathrm{H}$; 6, fraction 26 from $\mathrm{P} 2-\mathrm{H} ; 7$, lactoferrin isolated by one-step chromatography; 8 , transferrin (Sigma). 


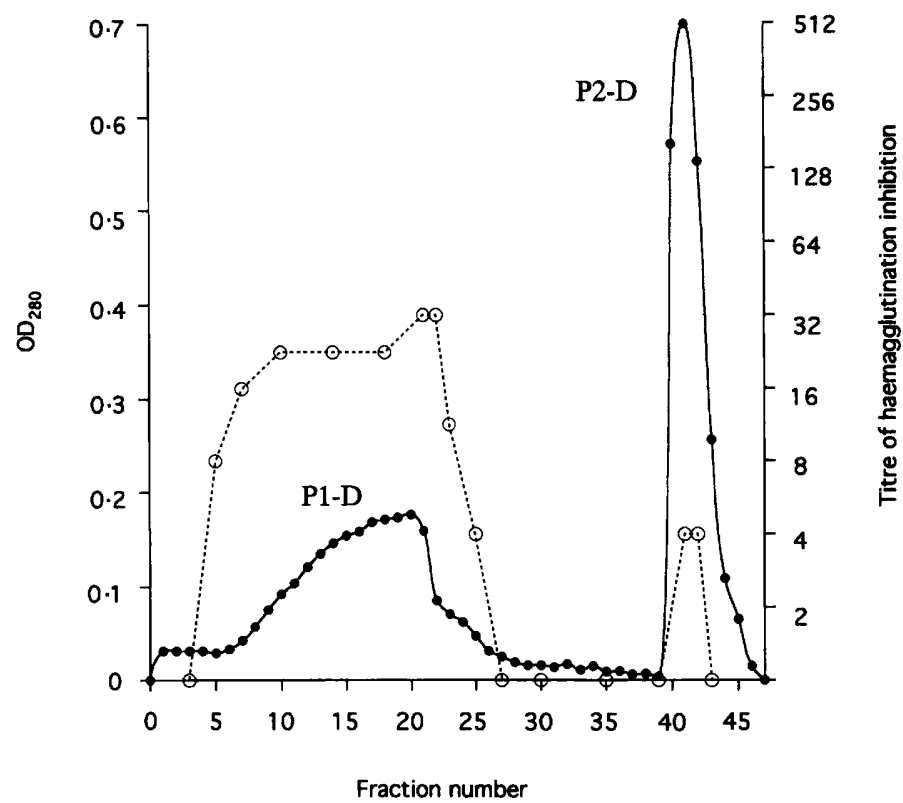

Fig. 3. Chromatography of the pooled fractions from P2-S on DEAE cellulose column $(2 \cdot 1 \mathrm{~cm} \times 25 \mathrm{~cm})$. The peaks were monitored at $280 \mathrm{~nm}$ (- - ) The unbound proteins (P1-D) were eluted in 0.01 $\mathrm{M}$ Tris- $\mathrm{HCl}, \mathrm{pH} \mathrm{7.6}$, with $0.05 \mathrm{M} \mathrm{NaCl}$ and the bound proteins (P2-D) were recovered in the same buffer with $1 \mathrm{M} \mathrm{NaCl}$; the flow rate was $36 \mathrm{ml} / \mathrm{h}$. Fractions of $6 \mathrm{ml}$ were collected and assayed for inhibition of the haemagglutination (-.. $-\cdots)$ induced by $E$. coli $\mathrm{CFAl}^{+}$TR $50 / 3$.

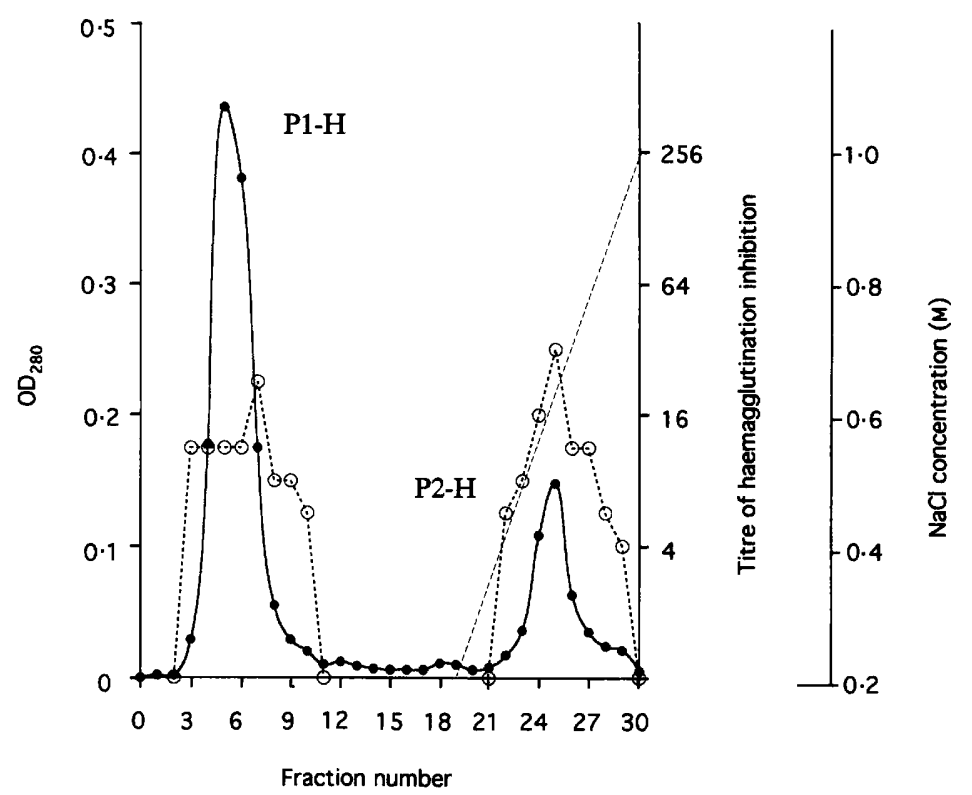

Fig. 4. Chromatography of the pooled and concentrated fractions of P1-D on heparin-sepharose $(1.5 \mathrm{~cm} \times 10 \mathrm{~cm})$. The peaks were monitored at $280 \mathrm{~nm}(--)$. The unbound proteins $(\mathrm{P} 1-\mathrm{H})$ were eluted in $0.05 \mathrm{M} \mathrm{Tris}-\mathrm{HCl}, \mathrm{pH} \mathrm{8.0}$, with $0.2 \mathrm{M} \mathrm{NaCl}$ and the bound proteins were recovered with an increasing $\mathrm{NaCl}$ gradient $(0.2 \mathrm{M}-1 \mathrm{M})(--)$ in the same buffer; the flow rate was $9.0 \mathrm{ml} / \mathrm{h}$. Fractions of $2.5 \mathrm{ml}$ were collected and assayed for inhibition of haemagglutination induced by E. coli CFAl ${ }^{+}$TR50/3 (-O-).

column with the starting buffer ${ }^{34}$ However, lactoferrin was retained but could be removed with $c .0 .6 \mathrm{M}$ $\mathrm{NaCl}{ }^{34,39}$ Fig. 4 shows the chromatographic profile of P1-D on heparin-sepharose and the inhibitory titres induced by the fractions. Both the protein fractions that did not bind to the column $(\mathrm{P} 1-\mathrm{H})$ and those that did (P2-H) inhibited haemagglutination. Electrophoretic analyses of the active fractions 3-6 showed the presence of a major protein of $79 \mathrm{kDa}$, corresponding to $\mathrm{fSC}$, and also, in very small amounts (only revealed by silver stain) another protein of lower mol. wt (not shown). However, fractions 7-10 showed only the fSC even when developed with silver stain (fig.
2, lane 5). Similarly, fractions 23-25 showed a major protein of $79 \mathrm{kDa}$ corresponding to lactoferrin and two other smaller proteins that could be visualised only by silver stain, but fractions 26-28 showed only the lactoferrin band (fig. 2, lane 6). These results showed that highly purified $\mathrm{ISC}$ and Lf were both able to inhibit the haemagglutination induced by ETEC $\mathrm{CFAl}^{+}$strains.

The purity of the $\mathrm{fSC}$ (fraction 7) and Lf (fraction 26) preparations was examined by two-dimensional gel electrophoresis and silver staining (fig. 5B and C). Both $\mathrm{fSC}$ and Lf preparations showed the presence of only one protein. The estimated pI ranges of $\mathrm{fSC}$ and 

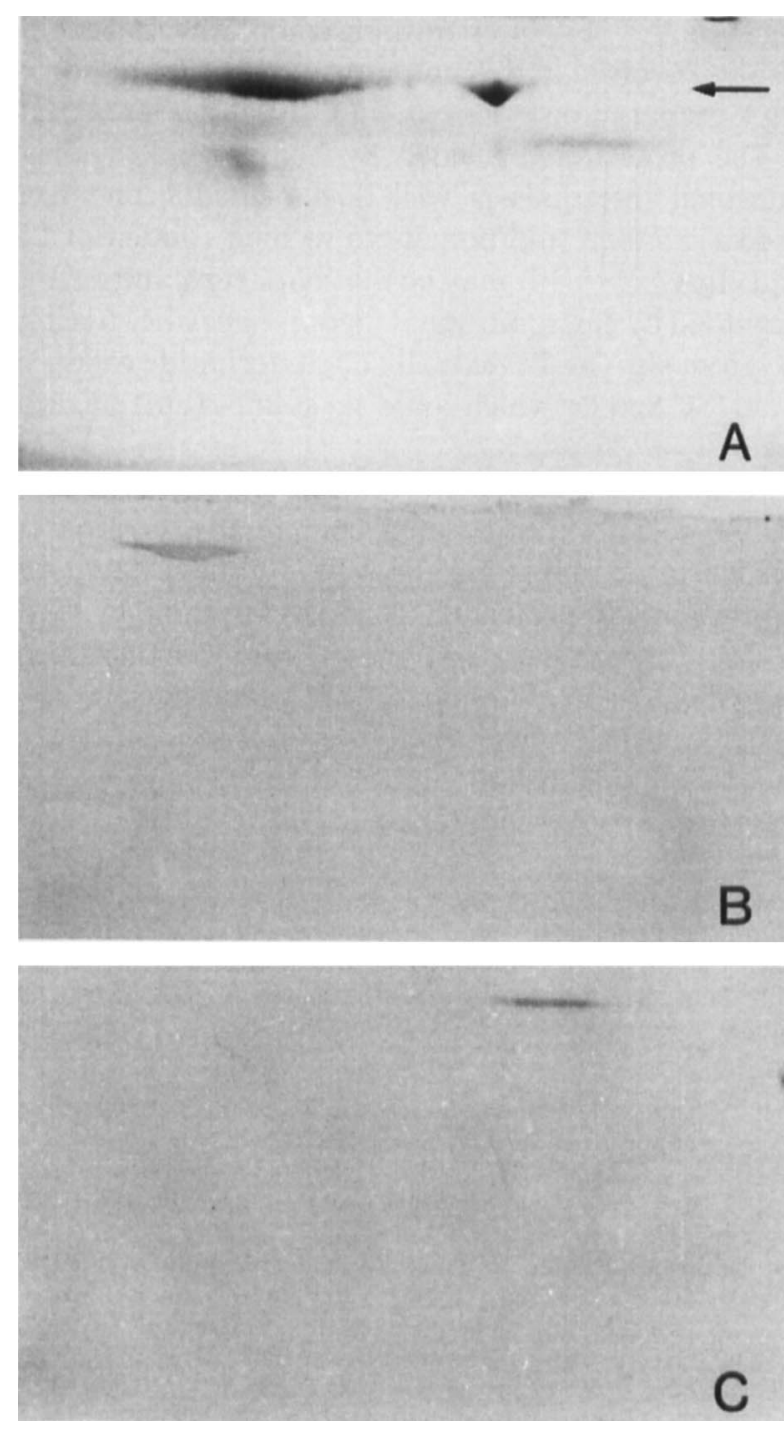

Fig. 5. Two-dimensional electrophoresis of human milk fractions. A, pooled and concentrated fractions of P1-D, arrow indicates two proteins of an estimated $79 \mathrm{kDa}$ with distinct iso-electric points; $\mathbf{B}$, fraction 26 from $\mathrm{P} 2-\mathrm{H}$, purified lactoferrin; C, fraction 7 from $\mathrm{P} 1-\mathrm{H}$, purified free secretory component.

Lf were $6 \cdot 9-7 \cdot 5$ and $7 \cdot 7-9 \cdot 3$ respectively, which is in good agreement with published values. ${ }^{43,44}$

The protein concentration of fraction 7 (fSC) was $1.4 \mathrm{mg} / \mathrm{ml}$, and its inhibitory titre was 24 . The inhibitory titre of fraction $26(\mathrm{Lf})$ was 12 , and its protein concentration was $1.2 \mathrm{mg} / \mathrm{ml}$. Therefore, the highest dilutions of $\mathrm{FSC}$ and Lf able to inhibit the haemagglutination induced by strain TR $50 / 3$ were $0.06 \mathrm{mg} / \mathrm{ml}$ and $0 \cdot 1 \mathrm{mg} / \mathrm{ml}$, respectively.

Lf in pure form and in high yield was also obtained by a single chromatographic step on heparinsepharose (fig. 2, lane 7). Although this Lf preparation was at least seven times more concentrated than the Lf preparation obtained by multiple chromatographic fractionation, it induced an inhibition titre at least sixfold lower. This may be explained by the differences in the procedures used for the isolation of $\mathrm{Lf}$. In the single chromatographic method, Veronal-HCl buffer was used throughout the procedure, whereas in the multiple chromatographic method Tris- $\mathrm{HCl}$ buffer was used. When the Lf isolated in Veronal buffer was dialysed against $\mathrm{Tris}-\mathrm{HCl}$, the inhibition titre of the preparation increased four-fold.

\section{Commercial lactoferrin and transferrin}

Commercially available lactoferrin from human milk and transferrin from human serum (which has a great structural analogy to lactoferrin) at $2 \mathrm{mg} / \mathrm{ml}$ and $10 \mathrm{mg} / \mathrm{ml}$, respectively, in $0.05 \mathrm{M}$ Tris- $\mathrm{HCl}, \mathrm{pH} \mathrm{7.6}$, were also assayed and shown to inhibit haemagglutination by ETEC $\mathrm{CFA}^{+}$strains. The lowest concentrations of lactoferrin and transferrin able to inhibit haemagglutination by strain TR50/3 were $0.03 \mathrm{mg} / \mathrm{ml}$ and $0.4 \mathrm{mg} / \mathrm{ml}$, respectively. These results corroborate our finding that purified preparations of Lf had inhibitory activity and showed that transferrin also inhibited the haemagglutination, but at a higher concentration.

The minimal inhibitory concentration of lactoferrin varied with the $\mathrm{CFAl}^{+}$strain used. The lowest concentration of lactoferrin that inhibited the haemagglutination induced by strain CD79a in our standard assay was $0.062 \mathrm{mg} / \mathrm{ml}$, whereas the highest concentration of lactoferrin used in the assay $(1 \mathrm{mg} / \mathrm{ml})$ did not inhibit the haemagglutination induced by strain $\mathrm{m} 452-\mathrm{Cl}$. However, when the inhibition assay was performed with bacterial suspensions adjusted to $150 \mu \mathrm{K}$ lett, strains CD79a and $\mathrm{m} 452-\mathrm{Cl}$ were inhibited by $0.02 \mathrm{mg} / \mathrm{ml}$ and $0.5 \mathrm{mg} / \mathrm{ml}$, respectively. These results may reflect the differing ability of each strain to express CFA1.

\section{Discussion}

This study demonstrated that both ISC and Lf in human milk inhibited adhesion to erythrocytes (haemagglutination) by ETEC CFA1 ${ }^{+}$strains. Human serum transferrin, which has a great structural analogy to $\mathrm{Lf},{ }^{28}$ also inhibited haemagglutination but at higher concentrations than $\mathrm{Lf}$.

Lf is considered to be an important non-specific defence factor against gastrointestinal infections by its iron-scavenging ability and consequent iron deprivation of micro-organisms. ${ }^{12,13,17,18}$ More recently, specific Lf-binding receptors have been described in several bacterial pathogens. ${ }^{19-22}$ Lf binding to a bacterial surface may damage the outer cell membrane and enhance the antimicrobial activity of $\mathrm{Lf}^{23,45}$ Studying the specific binding of Lf to $E$. coli isolated from human intestinal infection, Naidu et al. ${ }^{24}$ showed that ETEC strains bound significantly more Lf than other pathogenic groups. As we found that Lf also inhibits ETEC adhesion, it may indicate that Lf binds to CFAs which are found only in ETEC strains.

Previous studies ${ }^{9,15,26}$ have established the association between the presence of fucosylated oligosaccharides in human milk and adhesion inhibition of ETEC and EPEC strains to eukaryotic cells. Our findings may support these reports, as the sugar chain 
patterns of $\mathrm{fSC}$ and Lf are similar and rich in fucosylated oligosaccharide residues. ${ }^{28,30}$ Some of the oligosaccharides found to inhibit bacterial adherence might even be the degradation products of glycocompounds of the milk, as it is known that human milk contains specific hydrolytic enzymes ${ }^{46}$ and $\mathrm{FSC}$ is very sensitive to proteolysis. ${ }^{32,34}$ Furthermore, fucosecontaining glycopeptides from Lf were shown to inhibit the adherence of Shigella flexneri to intestinal cells. ${ }^{47}$

There is little information about the role of $\mathrm{SSC}$ in secretions but some workers suggest that it may have a protective role against diarrhoea. ${ }^{48,49}$ This report showed that ISC inhibited the adherence of ETEC strains in vitro, indicating that this compound may be an important non-specific defence factor because it is also found in intestinal secretions, ${ }^{50}$ hence providing protection for the mucous membranes which are the initial target in most infections.

We, as well as other authors, ${ }^{9,41}$ have verified that the immunoglobulin fraction (P1-S) also inhibited bacterial adherence. As the main immunoglobulin in human milk is $\operatorname{SIgA}$ and its molecule contains covalently bound SC, the inhibitory effect of sIgA may be partially due to the bound SC. In this context, Lf is a strongly basic protein which has been shown to

\section{References}

1. Black RE, Lopez de Romana G, Brown KH, Bravo N, Bazalar OG, Kanashiro HC. Incidence and etiology of infantile diarrhea and major routes of transmission in Huascar, Peru. Am J Epidemiol 1989; 129: 785-799.

2. Black RE, Merson MH, Rahman ASMM et al. A two-year study of bacterial, viral, and parasitic agents associated with diarrhea in Bangladesh. $J$ Infect Dis 1980; 142 660-664.

3. Guerrant RL, Kirchhoff LV, Shields DS et al. Prospective study of diarrheal illnesses in Northeastern Brazil: patterns of disease, nutritional impact, etiologies, and risk factor. $J$ Infect Dis 1983; 148: 986-997.

4. Levine MM. Escherichia coli that cause diarrhea: enterotoxigenic, enteropathogenic, enteroinvasive, enterohemorrhagic, and enteroadherent. J Infect Dis 1987; 155 : 377-389.

5. Changchawalit $\mathrm{S}$, Echeverria $\mathrm{P}$, Taylor DN et al. Colonization factors associated with enterotoxigenic Escherichia coli isolated in Thailand. Infect Immun 1984; 45: 525-527.

6. López-Vidal Y, Calva, JJ, Trujillo A et al. Enterotoxins and adhesins of enterotoxigenic Escherichia coli: are they risk factors for acute diarrhea in the community? J Infect Dis $1990 ; 162: 442-447$

7. Kovar MG, Serdula MK, Marks JS, Fraser DW. Review of the epidemiologic evidence for an association between infant feeding and infant health. Pediatrics 1984; 74: 615-638.

8. Young HB, Buckley AE, Hamza M, Mandarano C. Milk and lactation: some social and developmental correlates among 1000 infants. Pediatrics 1982; 69: 169-175.

9. Cravioto A, Tello A, Villafan H, Ruiz J, Vedovo S, Neeser JR. Inhibition of localized adhesion of enteropathogenic Escherichia coli to HEp-2 cells by immunoglobulin and oligosaccharide fractions of human colostrum and breast milk. J Infect Dis 1991; 163: 1247-1255.

10. Cruz JR, Gil L, Cano F, Caceres P, Pareja G. Breast milk antiEscherichia coli heat-labile toxin IgA antibodies protect against toxin-induced infantile diarrhea. Acta Paediatr Scand 1988; 77: 658-662.

11. Glass RI, Svennerholm A-M, Stoll BJ et al. Protection against cholera in breast-fed children by antibodies in breast milk. $N$ Engl J Med 1983; 308: 1389-1392.

12. Brock JH. Lactoferrin in human milk : its role in iron absorption interact electrostatically with acidic molecules including $\operatorname{sIgA},{ }^{34,51}$ very often forming complexes, and could also be involved in the inhibition of adhesion by some sIgA preparations.

The protection provided by human milk against intestinal infections is well documented ${ }^{7,8}$ and has been attributed traditionally to its high content of $\mathrm{Lf}$ and SIgA. ${ }^{9-13,17,18}$ It may be that both $\operatorname{SIgA}$ and Lf are degraded by gastrointestinal digestive enzymes freeing SC from SIgA and eventually oligosaccharide residues from $\mathrm{SSC}$ and Lf, which could act as important defence factors.

Despite all the evidence indicating a relevant protective role for the isolated compounds, caution is needed in extrapolating the results obtained in vitro to explain the protection conferred by human milk in vivo, since it may not reflect the real conditions to which these compounds are submitted in the gastrointestinal tract. Therefore, in-vivo studies are required to establish the role of $\mathrm{Lf}$ and $\mathrm{fSC}$ against the adhesive capacity of enteric pathogens.

We are grateful to Drs R. Giugliano, B. D. de Lima and C. Martins de Sá for many helpful discussions and suggestions, H. P Coelho and A. C. A. Lobo for technical assistance and the Human Milk Bank of Hospital Regional da Asa Sul for providing milk samples.

and protection against enteric infection in the newborn infant. Arch Dis Child 1980; 55: 417-421.

13. Bullen JJ, Rogers HJ, Leigh L. Iron-binding proteins in milk and resistance to Escherichia coli infection in infants. $B M J$ 1972; 1: 69-75.

14. Jelliffe DB, Jelliffe EPF. Protection and hazards. In: Jelliffe DB, Jelliffe EPF (eds) Human milk in the modern world. Psychosocial, nutritional and economic significance. Oxford, Oxford University Press. 1978: 84-112.

15. Newburg DS, Pickering LK, McCluer RH, Cleary TG Fucosylated oligosaccharides of human milk protect suckling mice from heat-stable enterotoxin of Escherichia coli. $J$ Infect Dis 1990 ; 162: 1075-1080.

16. Reiter B, Oram JD. Bacterial inhibitors in milk and other biological fluids. Nature 1967; 216: 328-330.

17. Griffiths E, Humphreys J. Bacteriostatic effect of human milk and bovine colostrum on Escherichia coli: importance of bicarbonate. Infect Immun 1977; 15: 396-401.

18. Oram JD, Reiter B. Inhibition of bacteria by lactoferrin and other iron-chelating agents. Biochim Biophys Acta 1968; 170: $351-365$.

19. Lee BC, Schryvers AB. Specificity of the lactoferrin and transferrin receptors in Neisseria gonorrhoeae. Mol Microbiol 1988; 2: 827-829.

20. Naidu AS, Andersson M, Forsgren A. Identification of a human lactoferrin-binding protein in Staphylococcus aureus. J Med Microbiol 1992; 36: 177-183.

21. Schryvers AB. Identification of the transferrin- and lactoferrinbinding proteins in Haemophilus influenzae. $\mathrm{J}$ Med Microbiol 1989; 29: 121-130.

22. Tigyi Z, Kishore AR, Mæland JA, Forsgren A, Naidu AS Lactoferrin-binding proteins in Shigella flexneri. Infect Immun 1992; 60: 2619-2626.

23. Dalamastri C, Valenti P, Visca P, Orsi N. Enhanced antimicrobial activity of lactoferrin by binding to the bacterial surface. Microbiologica 1978 ; 11 : 225-230

24. Naidu SS, Erdei J, Czirók É et al. Specific binding of lactoferrin to Escherichia coli isolated from human intestinal infections. APMIS 1991; 99: 1142-1150.

25. Andersson B, Porras O, Hanson LA, Lagergård TS, SvanborgEdén C. Inhibition of attachment of Streptococcus pneumoniae and Haemophilus influenzae by human milk and receptor oligosaccharides. J Infect Dis 1986; 153 : 232-237. 
26. Ashkenazi S, Mirelman D. Nonimmunoglobulin fraction of human milk inhibits the adherence of certain enterotoxigenic Escherichia coli strains to guinea pig intestinal tract. Pediatr Res 1987; 22: 130-134.

27. Holmgren J, Svennerholm A-M, Lindblad M. Receptor-like glycocompounds in human milk that inhibit classical and El Tor Vibrio cholerae cell adherence (hemagglutination). Infect Immun 1983; 39: 147-154.

28. Aisen P, Listowsky I. Iron transport and storage proteins. Annu Rev Biochem 1980; 49: 357-393.

29. Brandtzaeg P. Human secretory immunoglobulins. 4. Quantitation of free secretory piece. Acta Path Microbiol Scand 1971; Section B 79: 189-203.

30. Mizoguchi A, Mizuochi T, Kobata A. Structures of the carbohydrate moieties of secretory component purified from human milk. $J$ Biol Chem 1982; 257: 9612-9621.

31. Chintalacharuvu KR, Piskurich JF, Lamm ME, Kaetzel CS. Cell polarity regulates the release of secretory component, the epithelial receptor for polymeric immunoglobulins, from the surface of HT-29 colon carcinoma cells. $J$ Cell Physiol 1991; 148: 35-47.

32. Mestecky J, McGhee JR. Immunoglobulin A (IgA): molecular and cellular interactions involved in IgA biosynthesis and immune response. Adv Immunol 1987; 40: 153-245.

33. Mostov KE, Deitcher DL. Polymeric immunoglobulin receptor expressed in MDCK cells transcytoses IgA. Cell 1986; 46: 613-621.

34. Mestecky J, Kilian M. Immunoglobulin A (IgA). Methods Enzymol 1985; 116: 37-75.

35. Bradford MM. A rapid and sensitive method for quantitation of microgram quantities of protein utilizing the principle of protein-dye binding. Anal Biochem 1976; 72 : 248-254.

36. Laemmli UK. Cleavage of structural proteins during the assembly of the head of bacteriophage T4. Nature 1970; 227: $680-685$.

37. Blum H, Beier $H$, Gross HJ. Improved silver staining of plant proteins, RNA and DNA in polyacrylamide gels. Electrophoresis 1987 ; 8: 93-99.

38. O'Farrell PZ, Goodman H, O'Farrell PH. High resolution two-dimensional electrophoresis of basic as well as acidic proteins. Cell 1977; 12: 1133-1141.

39. Blackberg L, Hernell $O$. Isolation of lactoferrin from human whey by a single chromatographic step. FEBS Lett 1980 ; 109: 180-183.
40. Evans DG, Evans DJ, Tjoa W. Hemagglutination of human group A erythrocytes by enterotoxigenic Escherichia coli isolated from adults with diarrhea: correlation with colonization factor. Infect Immun 1977; 18: 330-337.

41. Holmgren J, Svennerholm AM, Ahren C. Nonimmunoglobulin fraction of human milk inhibits bacterial adhesion (hemagglutination) and enterotoxin binding of Escherichia coli and Vibrio cholerae. Infect Immun 1981; 33: 136-141.

42. Evans DG, Evans DJ. New surface-associated heat-labile colonization factor antigen (CFA/II) produced by enterotoxigenic Escherichia coli of serogroups $\mathrm{O6}$ and $\mathrm{O8}$. Infect Immun 1978; 21 : 638-647.

43. Malamud D, Drysdale JW. Isoelectric points of proteins: a table. Anal Biochem 1978; 86: 620-647.

44. Roberts TK, Masson PL, Heremans JF. Heterogeneity of human lactoferrin. In: Bratanov $K$, Edwards $R G$, Vulchanov VH, Dikov V, Somlev B (eds) Immunology of reproduction. Sofia, Bulgarian Academy of Sciences Press. 1973: 706.

45. Ellison RT, Giehl TJ, LaForce FM. Damage of the outer membrane of enteric gram-negative bacteria by lactoferrin and transferrin. Infect Immun 1988; 56: 2774-2781.

46. Coppa GV, Catassi C, Felici L, Gabrielli O, Giorgi PL. Acid glycohydrolases in human colostrum. In: Proceedings of XX Annual Meeting of European Society for Paediatric Gastroenterology and Nutrition (ESPGAN), Lisbon, Portugal. 1987: 90.

47. Izhar M, Nuchamowitz Y, Mirelman D. Adherence of Shigella flexneri to guinea-pig intestinal cells is mediated by a mucosal adhesin. Infect Immun 1982; 35: 1110-1118.

48. Buts JP, Bernasconi P, Vaerman JP, Dive C. Stimulation of secretory IgA and secretory component of immunoglobulins in small intestine of rats treated with Saccharomyces boulardii. Dig Dis Sci 1990; 35: 251-256.

49. Nussinson E, Lahav M, Berebi A, Estrov Z, Zur S, Resnitzky P. Secretory piece and IgA deficiency in a patient with Waldenstrom's macroglobulinemia. Am $J$ Gastroenterol 1986; 81 : 995-998.

50. Ahnen DA, Brown WR, Kloppel TM. Secretory component: the polymeric immunoglobulin receptor. What's in it for the gastroenterologist and hematologist? Gastroenterology $1985 ; 89$ : 667-682.

51. Hekman A. Association of lactoferrin with other proteins, as demonstrated by changes in electrophoretic mobility. Biochim Biophys Acta 1971; 251 : 380-387. 